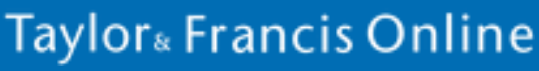

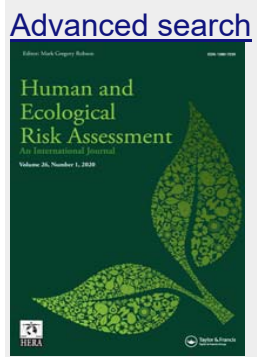

Human and Ecological Risk Assessment: An International Journal

Volume 26, 2020 - Issue 1

Submit an article Journal homepage

\section{Chemical speciation and health risks of airborne heavy metals around an industrial community in Nigeria}

\author{
Winifred U. Anake \\ Nsikak U. Benson \\ Imokhai Theophilus Tenebe \\ PraiseGod Chidozie Emenike \\ Godson R. E. E Ana \\ \& \\ Suojiang Zhang
}

Pages 242-254 | Received 12 Jun 2018, Accepted 23 Jul 2018, Published online: 29 Oct 2018

- Download citation

- https://doi.org/10.1080/10807039.2018.1504672 


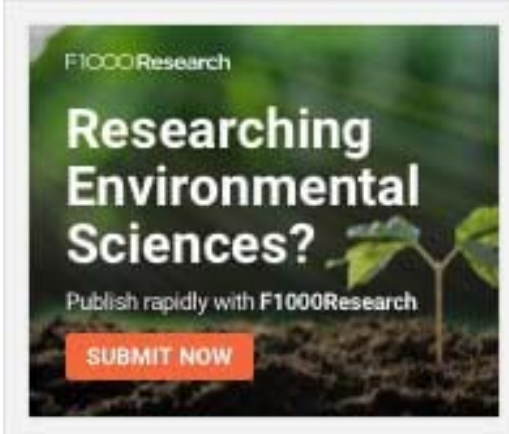

\begin{abstract}
Quantification of $\mathrm{PM}_{2.5}$ (particulate matter $<2.5 \mu \mathrm{m}$ ) bound heavy metals and their potential health risks were carried out around a cement manufacturing company in Ewekoro, Nigeria. The $\mathrm{PM}_{2.5}$ samples were collected using Environtech gravimetric sampler. A four-staged sequential extraction procedure was used to fractionate $\mathrm{PM}_{2.5}$ bound chromium ( $\mathrm{Cr}$ ), lead $(\mathrm{Pb})$, aluminum (Al), copper $(\mathrm{Cu})$, and silver $(\mathrm{Ag})$, and further analyzed using inductively coupled plasma mass spectrometry. Chemical speciation results reveal bioavailable levels of $\mathrm{Pb}\left(4.05 \mu \mathrm{g} / \mathrm{m}^{3}\right), \mathrm{Cr}\left(10.75 \mu \mathrm{g} / \mathrm{m}^{3}\right), \mathrm{Al}$ $\left(16.47 \mu \mathrm{g} / \mathrm{m}^{3}\right)$, Cu $\left(4.38 \mathrm{E}-01 \mu \mathrm{g} / \mathrm{m}^{3}\right)$, and $\mathrm{Ag}\left(1.22 \mathrm{E}-02 \mu \mathrm{g} / \mathrm{m}^{3}\right)$ in the airborne particulates. $\mathrm{Pb}$ and $\mathrm{Cr}$ levels exceeded the World Health Organization allowable limit of 0.5 and $2.5 \mathrm{E}-05 \mu \mathrm{g} / \mathrm{m}^{3}$, respectively. The labile phases showed strong indication of the presence of $\mathrm{Cr}$ and $\mathrm{Cu}$ metal. Excess cancer risks exposure for adults, outdoor workers and children were higher than the acceptable risk target level of 1E-06. Noncarcinogenic health risk estimated using hazard quotients (HQs) and hazard indices $(\mathrm{HIs})$ showed ingestion route within the safe level of $\mathrm{HI}<1$ implying no adverse effect while inhalation route exceeded the safe level for all receptors. Enforcement of pollution control by authorized agencies, and screening of greenbelts as sinks for air pollutants is strongly recommended.
\end{abstract}

Keywords:

air pollutionPM ${ }_{25}$ heavy metalssequential extraction methodhealth risk assessment

\title{
Acknowledgments
}

The authors gratefully thank Prof. Zhang Suojiang, the Director of the Institute of Process Engineering, Chinese Academy of Sciences, Beijing, China, for providing necessary laboratory support and Covenant University, Ota, Nigeria for providing a research base for this work. Also, we appreciate the anonymous reviewers for their constructive comments and suggestions.

\section{Disclosure statement}

No potential conflict of interest was reported by the authors. 
- More Share Options 